\title{
MED26 wt Allele
}

National Cancer Institute

\section{Source}

National Cancer Institute. MED26 wt Allele. NCI Thesaurus. Code C52210.

Human MED26 wild-type allele is located in the vicinity of 19p13.12 and is approximately $53 \mathrm{~kb}$ in length. This allele, which encodes mediator of RNA polymerase II transcription subunit 26 protein, is involved in transcriptional enhancement. 